Modern Asian Studies 46, 2 (2012) pp. 283-302. (C) Cambridge University Press 2012 doi:10.1017/S0026749X11000801 First published online 13 February 2012

\title{
Nation, Race, and Language: Discussing transnational identities in colonial Singapore, circa 1930
}

\author{
CHUA AI LIN
}

Department of History, Faculty of Arts and Social Sciences, National University of Singapore, I I Arts Link, AS I 05-27 Singapore I I 757 O Email:hiscal@nus.edu.sg

\begin{abstract}
Around 1930, at a time of rising nationalisms in China and India, Englisheducated Chinese and Indians in the British colony of Singapore debated with great intensity the issue of national identity. They sought to clarify their own position as members of ethnic communities of immigrant origin, while remaining individuals who identified the territory of British Malaya as their home. Readers' letters published in the Malaya Tribune, an English-medium newspaper founded to serve the interests of Anglophone Asians, questioned prevailing assumptions of how to define a nation from the perspectives of territory, political loyalty, race, and language. Lived circumstances in Malaya proved that being Chinese or Indian could encompass a range of political, cultural, and linguistic characteristics, rather than a homogenous identity as promoted by nationalist movements of the time. Through these debates, Chinese and Indians in Malaya found ways to simultaneously reaffirm their ethnic pride as well as their sense of being 'Malayan'.
\end{abstract}

\section{Introduction}

As a cosmopolitan port city under British colonial rule, Singapore was (and still is) a key site of cultural interaction not only in terms of East meets West but also between the many Asian diasporic communities who populated the island. Colonial Singapore society was richly diverse and complex, first because of its many component ethnicities and, second, because different waves of immigration created communities with varying degrees of attachment to their land of settlement. The main racial groups in the 193 os were the Chinese, comprising nearly three-quarters of the population; Malay peoples from the surrounding 
peninsular and archipelagic region, making up just over 12 per cent; and Indians who comprised the remaining nine per cent. ${ }^{1}$ By the early decades of the twentieth century, there were significant numbers of non-Malays whose families had been living in Malaya for generations among those who had decided to settle permanently in Malaya. ${ }^{2}$ In an era of new Asian nationalisms, the Chinese and Indians in Singapore found themselves forced to conceptualize their identities-national, racial, and linguistic - in the context of their status as transnational communities. It was precisely in contact zones like Singapore, away from the centres of Chinese and Indian civilization and far from the imperial metropole, that hybrid lived experiences forced the redefinition of ideas which prevailed in both Asia and Europe. This process is one that has received little attention from scholars of Malaysia and Singapore because of the overwhelming tendency to study ethnic communities in isolation and to view these communities through the lenses of the colonial state or vernacular sources, both of which enhanced the impression of a Furnivallian plural society while overlooking the forms of interaction between different ethnic groups. By turning our attention instead to the multi-ethnic sphere of Anglophone Asians, a different picture emerges. The common lingua franca of English, and the existence of Anglophone Asian forums like the Malaya Tribune newspaper, provided the conditions for a deep and intellectual engagement of different cultures, where Chinese and Indians grappled to reconcile their complex identities with mainstream essentialist notions of the nation.

\section{The Anglophone Asian public sphere}

The Anglophone sphere provided a space in which individuals from different ethnic backgrounds could engage directly with each other. While English-educated Asians shared a common colonial schooling,

${ }^{1}$ C. A. Vlieland, British Malaya (the Colony of the Straits Settlements and the Malay States Under British Protection, Namely the Federated States of Perak, Selangor, Negri Sembilan and Pahang and the States of Johore, Kedah, Kelantan, Trengganu, Perlis and Brunei): A Report on the 193 I Census and on Certain Problems of Vital Statistics (London: Crown Agents for the Colonies, 1932), Table 1.

${ }^{2}$ Under British colonial administration, the Malayan peninsula was known as 'Malaya'. The present-day sovereign state of Malaysia was formed in 1963, combining Malaya with two other former British territories on Borneo Island - Sabah and Sarawak. 
they were also able to tap into their own vernacular communities, albeit with varying levels of fluency and literacy. At times, they introduced ideas that were circulating in their own vernacular circles to a cross-ethnic forum, and opened up opportunities for the redefinition of concepts to fit the complex situation of multi-ethnic colonial society. The direct engagement between Chinese- and Indianbased ethnic nationalisms in Malaya's English-language press played a vital role in developing readers' understanding of nation and national identity in a transnational context.

The Malaya Tribune newspaper is one of the best sources of this Asian Anglophone sphere. It was founded in Singapore in 1914 as the first English language daily newspaper for an Asian readership. Financial backing came from prominent local citizens: Lim Boon Keng, Koh San Hin, Ong Boon Tat, See Tiong Wah, S. Q. Wong, Lee Chim Tuan, and Tan Cheng Lock from the Straits Chinese community; ${ }^{3}$ two Indians, M. V. Pillai and A. M. S. Angullia; a Eurasian, Alexander Westerhout; and Ezra Aaron Elias who was Jewish. Only Asians and Eurasians were allowed on the board of directors or to hold shares. The primary motivation behind the establishment of the Tribune was the need for a newspaper to defend the interests of the Asian, Englishliterate, permanently settled community who were not served by the main dailies, the Straits Times and the Singapore Free Press, as both newspapers were produced for the elite, white community. ${ }^{4}$ Calling itself the 'People's Paper', the Malaya Tribune was priced at five cents, half the cost of both the Straits Times and the Singapore Free Press. By mid-1934, the Malaya Tribune was the best-selling daily paper in Malaya, testifying to the strength of the Tribune's agenda. ${ }^{5}$ The 1930 s saw the paper expand into a group of newspapers: a Malaya-wide Sunday Tribune in 1933, a Federated Malay States edition from 1935, a Morning Tribune circulated in Singapore from 1936, and a Penang

${ }^{3}$ The term 'Straits Chinese' is explained in a later section.

${ }^{4}$ Malaya Tribune, Special Supplement, 18 January 1935, p. 1; Silver Jubilee Supplement, 16 January 1939, pp. 2, 6; Peter Laurie Burns, 'The English Language Newspapers of Singapore, $19^{1} 5^{-195^{1}}$ ', Academic Exercise, University of Malaya, 1957 , p. 28.

5 From May 1934 onwards, the daily slogan underneath the paper's name on the front page read, 'Largest Circulation of Any Daily Newspaper in Malaya'. Circulation figures for the paper were professionally audited by the chartered accountants, Messrs. Derrick and Co., and the figures were open to inspection by the public. Malaya Tribune, Special Supplement, 18 January 1935, p. 1; and 3 February 1937, p. 10. 
edition started in $1938 .{ }^{6}$ While based in Singapore, the Tribune came to serve a much wider geographical community and was one expression of how Singapore, as the administrative and economic capital of British Malaya, led the way for an Asian, English-language public sphere. Perhaps because the Malaya Tribune ceased publication in $195^{1}$, in contrast to the dominant status of the Straits Times in Singapore today, little scholarly research has made use of the Tribune, resulting in a historiography that ironically overlooks the voice of the educated classes and Asian elites in twentieth-century colonial Singapore.

\section{The transnational debate: 'What is a nation?'}

Cross-national debates consistently filled the correspondence pages of the Malaya Tribune for many months during the years 1929-30. The most important question raised was, 'What is a nation?' Chinese and Indians tried to outdo one another, each arguing that their own motherland was more of a nation than the others'. ${ }^{7}$ In the course of this debate, readers offered their definitions of a nation. For example, 'Kiran' questioned the degree of diversity that was acceptable within a nation. ${ }^{8}$ To him, 'geographical position, racial oneness, and cultural unity are the main aspects which determine the claim of a people to nationhood'. To Yao Enguan, 'a nation is a country whose people are common in Government, literature (spoken dialects may vary but not writing), customs and habits, physical features and other general cultural aspects'. ${ }^{9}$ Another reader, Lee Hock Lye, opined that 'the word "nation" is applied to the people generally, born of the same stock, inhabiting the same country, under the same Government'. ${ }^{10}$ All three definitions comprised the same main elements: a distinct geographical territory under a single government, racial homogeneity, and similarity of language and culture.

A national agenda had the effect of attempting to smooth over sub-ethnic or sectarian differences within the larger nation, for

${ }^{6}$ Malaya Tribune, Silver Jubilee Supplement, 16 January 1939, p. 2; 29 May 1933, p. 8; 28 February 1935, p. 8; 29January 1936, p. 14; and 1 November 1938, p. 14.

${ }^{7}$ See letters in Malaya Tribune, 14 September 1929, p. $11 ; 9$ October 1929, p. 10; 27 September 1929, p. 11 ; 10 October 1929, p. 11 ; 11 October 1929, p. 11 ; 12 October 1929, p. 10; 14 October 1929, p. 12; 10 October 1929, p. 11 ; and 12 October 1929, p. 10.

${ }_{9}^{8}$ Malaya Tribune, 27 September 1929, p. 11.

${ }^{9}$ Malaya Tribune, 4 October 1929, p. 11.

${ }^{10}$ Malaya Tribune, 9 October 1929, p. 10. 
example between Chinese dialect groups in China and different Indian regional and religious communities in India. These tensions impeded the smooth development of the respective nationalisms, especially in India, and were carried over into the Malayan context where many sub-ethnic groups lived in close proximity. What was distinctive about Malaya was that domiciled Indians and Chinese found themselves caught between two possible national entities-that of their motherlands with whose people they shared the same ethnicity, language, and culture, and that of British Malaya, which was a distinct geographical entity under a single British administration, where they also shared the common languages of Malay and English, as well as exposure to British culture.

\section{The nation as a geopolitical entity}

\section{The Straits Chinese}

The term 'Straits Chinese' was used at the time to refer to the community of Chinese people with distinct social, political, and cultural markers that set them apart from the majority of Chinese in Malaya. They identified themselves geographically with Malaya, or, more specifically, with the Straits Settlements, hence the name 'Straits Chinese'. As a social grouping with an established history tied to the economic opportunities of European imperialism, the term also usually implied a higher social status of relative wealth and Englishmedium education. In practice, those who identified as Straits Chinese varied in how long their families had been in Malaya, but shared the common factors of being of middle class or higher status, and having chosen Anglophone culture as well as to be permanently domiciled in Malaya. ${ }^{11}$

${ }^{11}$ Most contemporary definitions of the Straits Chinese include characteristics of a Malay-influenced hybrid culture in terms of language, dress, and food. However, during the interwar period, 'Straits Chinese' also included those who were born in the Straits Settlements and whose families may have been in Malaya for generations but did not exhibit a Malay-influenced culture. For more detailed discussion of the definition of Straits Chinese, see Png Poh Seng, 'The Straits Chinese in Singapore: A Case of Local Identity and Socio-Cultural Accommodation', Journal of Southeast Asian History, 10 (1), March 1965, pp. 96-99; John Clammer, Straits Chinese Society: Studies in the Sociology of the Baba Communities of Malaysia and Singapore (Singapore: Singapore University Press, 1980), pp. 2-1 1; and Jürgen Rudolph, Reconstructing Identities: A Social History of the Babas in Singapore (Aldershot: Ashgate, 1998), pp. 25-73. 
For the Straits Chinese, it was clear that the geopolitical entity in which they lived and with which they identified was not China, but British Malaya. The problem was that under Chinese nationality law, anyone with Chinese parentage was automatically a national of China, resulting in Malayan-born Chinese holding dual nationality of both China and Britain. ${ }^{12}$ It was an unfortunate situation for the Straits Chinese: they did not want to hold Chinese nationality as this could subject them to Chinese conscription law and Chinese jurisdiction when visiting China. More importantly, being a Chinese citizen led the colonial government to cast doubts on their loyalty to the British empire, and ethnic Malays to question their attachment to Malaya.

The Straits Chinese' position was further jeopardized by the mass of Chinese-speaking and China-oriented Chinese in Malaya. As a minority within the total Chinese population, ${ }^{13}$ the Straits Chinese fell victim to the common misconception that the Chinese community was a homogenous body of Chinese citizens, uniform in its primary loyalty to China. This was especially so because of other Chinese British subjects-particularly the vernacular-speaking-who were firmly in this group. As an editorial in the Straits Echo, a Penang newspaper, put it:

[in the] question of Straits-born Chinese being prevented from occupying high positions in the Public Services... the chief drawback to its consummation is the fact that some Straits-born Chinese-though only a few-do not sufficiently appreciate the fact that China is not and has never been their native land. The result of this is that the European community is often under the mistaken impression that Straits-born Chinese consider themselves Chinese citizens and not British subjects. ${ }^{14}$

${ }^{12}$ For an economic perspective on dual nationality, see Man-Houng Lin, 'Overseas Chinese Merchants and Multiple Nationality: A Means for Reducing Commercial Risk (1895-1935)', Modern Asian Studies, 35 (4), 2001.

${ }^{13}$ From the available statistics, it is possible to arrive at a general idea of the numbers of Straits Chinese, as distinct from nominally Straits Settlements-born Chinese in Singapore, if we assume that (a) a Straits Chinese was born in the Straits Settlements; (b) was literate in English (although this artificially presumes that all Straits Chinese were able to pay the school fees at English schools); and (c) that almost all English-literate Chinese in Singapore received their education in British Malaya. By calculating the percentage of English-literate Chinese over the total number of Straits Settlements-born Chinese in Singapore, we arrive at a figure of 40.22 per cent (Census of British Malaya I93 I, Tables 149 and 100). Given that Straits Settlements-born Chinese made up 35.11 per cent of the Singapore population, the English-speaking, permanently settled Straits Chinese would have comprised about 14 per cent of the total Chinese population in Singapore.

14 Straits Echo editorial, 10 January 1931, p. 8. Reprinted in the Malaya Tribune, 16 January 1931, p. 4 . 
It was for this reason that Lim Cheng Ean, the Penang member of the Legislative Council, told his audience at the $\mathrm{Hu}$ Yew Seah society on 6 February 1931:

You must do your best to smash the idea that this is not our country... If you do not wish to do so, you are free to pack your belongings and go back to China leaving we Straits-born Chinese here alone so that our position may not be jeopardised. ${ }^{15}$

These debates taking place in Penang were quickly reported in Singapore, where circumstances were very similar.

Most Straits Chinese were therefore very concerned to denationalize themselves from China and to distinguish themselves from the China-oriented Chinese. The problem was that the conditions for denationalization under Chinese law were almost impossible to fulfil. First, any male between the ages of 18 and 45 was liable to be conscripted and could not be denationalized. Secondly, the administrative procedure required two Chinese businesses to sign a certificate of guarantee for the applicant and for the applicant to provide the original address in China of the ancestor who migrated to Malaya. For these reasons, a Straits Chinese who had been appointed to the Straits Settlements Civil Service could not obtain the denationalization certificate to be confirmed in his post. ${ }^{16}$ Even the application of the legislative councillor, Sir Ong Siang Song, was rejected as he had not met the necessary requirements. ${ }^{17}$

Many Straits Chinese also wanted to learn Mandarin and study Chinese literature and history. For example, the Singapore Chinese Mandarin School, which taught Mandarin via the English language, received much support from Anglophone Chinese after it opened. ${ }^{18}$ The Straits Chinese were also active in sending relief aid to China to help the victims of natural disasters and Japanese military aggression.

${ }^{15}$ Malaya Tribune, 12 February 1931, p. 12. The Hu Yew Seah (League of Helping Friends) was started in 1915 in Penang to promote the study of Chinese language and literature among the Straits Chinese, and by the late 193 os was noted to be 'the cultural centre for Penang Chinese'. One of the society's trustees, Heah Joo Seang, described its members as, 'Leaders of thought, lovers of truth, champions of the cause of justice, democracy and liberty': see Malaya Tribune, 14 December 1940, p. 6.

${ }_{16}$ Colonial Office (CO) file series CO 273/6o6/50055/3, Monthly Review of Chinese Affairs (MRCA) 57 (May 1935), p. 26; CO 273/628/50055/1, MRCA 77 (January 1937), p. 16. On conditions for joining the Straits Settlements Civil Service, see CO273/584/92144, encl. 3, Clementi to Cunliffe-Lister, 14 October 1932.

${ }_{17} \mathrm{CO} 273 / 628 / 5^{\text {OO }} 55^{/ 2}$, MRCA 82 (June 1937), p. $3^{2}$.

${ }^{18}$ Singapore Chinese Mandarin School, First Anniversary Special Magazine (Singapore: Hwa Nan Press, 1930). 
Although these actions were primarily cultural and humanitarian, they gave the impression that the political loyalties of the Straits Chinese lay with China. In order not to jeopardise their political position in Malaya, they repeatedly stressed that their cultural interest in things Chinese had no political intent. Lim Cheng Ean was one of the Straits Chinese who stressed the separation of cultural and political interests. When he spoke at the Hu Yew Seah on 6 February 1931, he pointed out that 'a Chinese could be a British subject and yet could cultivate in him the culture, custom and manners of the Chinese race' and that 'these two were neither conflicting nor contradictory to each other'. ${ }^{19}$

The desperate attempts of the Straits Chinese to denationalize from Chinese citizenship was an indication that they valued their legal and political ties with China less than their position in Malaya. Of the numerous readers' letters in the Malaya Tribune reacting to Sino-Japanese relations, most took a similar detached standpoint to that of other international observers who condemned Japan's blatant disregard for China's sovereignty. Letters pleading for the Chinese in Malaya to go to the aid of China were comparatively less common. ${ }^{20}$ Where donations were made, for example by Straits Chinese brothers Ong Boon Tat and Ong Peng Hock who owned the New World amusement park, it is not easy to determine the extent to which they were motivated by feelings for China or simple humanitarian concern, as was the case with the various European firms which also made contributions to Chinese charitable causes. ${ }^{21}$

In general, the domiciled Chinese believed that dual loyalty was possible-that their cultural interest in things Chinese did not have any implications for their patriotism to the British empire. However, they refused to face the ultimate question of who they would support if war broke out between Britain and China. When some readers' letters posed this problem, the consistent response, including from the editors

19 Malaya Tribune, 12 February 1931, p. 12.

${ }^{20}$ See, for example, Malaya Tribune, 27 May 1929, p. 4; 28 February 1930, p. 3; 6 March 1930, p. 3. However, Straits Chinese concern for China did increase. By December 1936, aid to China had reached a level which the colonial government found worrying and legislation was introduced to stop donations to military causes. Proceedings of the Legislative Council of the Straits Settlements (PLCSS), [6]7 December 1936, B131-132. Following the outbreak of the Sino-Japanese war, public concern for the situation in China among the Straits Chinese became more marked, with correspondingly more donations.

${ }^{21}$ Malaya Tribune, 23 September 1931, p. 11. 
of the Malaya Tribune, was that such a question was irrelevant because that scenario would never come about. ${ }^{22}$

\section{The Indian community ${ }^{23}$}

Most Indians in Malaya would have been British subjects or British protected persons, regardless of whether they were born in India, the Straits Settlements or the Malay States. A common nationality between those in India and Indians living in Malaya would have allowed both sides to share the anti-British feeling of the Indian independence movement. Indeed, Indians in Malaya adopted many of the symbols of Gandhi's Indian nationalist movement. Politically charged expressions of anti-British feeling in India, such as the wearing of khaddar (traditional homespun cotton cloth), the singing of national songs, and the celebration of the birthdays of important Indian public figures, also became common in Malaya. However, just as with the large numbers of Straits Chinese who learned Mandarin without any intended diminution of their loyalty towards Britain, Indians in Malaya adopted these cultural markers out of ethnic pride and divested them of the political meaning they had in India. ${ }^{24}$

Unlike the overseas Chinese, who experienced constant encouragement from the Chinese government to draw them into the sphere of events in China, Indian politicians were divided in opinion on the level of interest Indians in Malaya should have in events taking place in their ethnic homeland. For example, Srinivasa Sastri, a leading politician from India, visited Malaya in 1936 to report to the Indian government on the status of Indians in Malaya. He gave speeches in Singapore and Kuala Lumpur, and in the latter, as in his final report, he exhorted Indians in Malaya to concentrate on uniting themselves to improve their position within Malaya and for the domiciled to identify with Malaya as far as possible. As Sastri

${ }^{22}$ Malaya Tribune, 13 January 1930, p. 11 ; 15January 1930, p. 11; 16 January 1930, p. 11 ; and 24 September 1932 , p. 4 .

${ }^{23}$ With Tamils comprising 6o.8 per cent of the total Indian population in Singapore, and 83 per cent of the total Indian population of the Straits Settlements (Census of British Malaya I93I, Table 62), it can be taken that, unless explicitly stated, the 'Indian' activity described in this paper reflected a largely Tamil perspective.

${ }^{24}$ Rajeswary Ampalavanar, 'Social and Political Developments in the Indian Community of Malaya 1920-41', MA thesis, University of Malaya, Kuala Lumpur, 1969 , pp. $63-65$. 
was an Indian leader with a history of active campaigning for the rights of overseas Indians in Kenya and South Africa, this was a strong signal to Indians in Malaya to develop a positive new Malayan political identity. ${ }^{25}$ On the other hand, when Pandit Nehru, president of the Indian National Congress, visited Malaya in May 1937 amid great enthusiasm from Indians across Malaya, he told local Indians 'to take a great interest in their motherland, which they could help financially and with which they should always remain in touch ${ }^{26}$ and declared that:

Their future is after all intimately and irrevocably bound up with the future of India and that on India's freedom depends their status, the protection of their interests and the place they occupy in the world. ${ }^{27}$

While the domiciled Chinese faced a lack of trust from the British authorities, Indians in Malaya did not face the same problem. Indian political activity, such as the close links between the Central Indian Association of Malaya (formed in 1936) and the Congress Party in India, did not threaten law and order in Malaya in the same way that Chinese organizations like the Kuomintang and the Malayan Communist Party did. The sectarian divisions in the Indian community, particularly the challenge of Tamil Dravidian subnationalism to the Brahmin-led Indian independence movement of the Congress Party, ${ }^{28}$ helped to keep the Indian community in Malaya as a whole from uniting around a common goal for India. Perhaps because of the direct anti-British sentiments present in politics in India, Indians in British Malaya tended to be cautious about supporting obviously seditious causes. This might have been the reason behind the Malaya Tribune's refusal to publish readers' letters on Indian politics,

${ }^{25}$ Malaya Tribune, 24 December 1936, p. 14; 7 January 1937, p. 7; and 12, 10 March 1937, p. 10. Michael Stenson, Class, Race and Colonialism in West Malaysia: The Indian Case (St Lucia: University of Queensland Press, 1980), p. 46. As early as 1930, Sastri had already been discouraging overseas Indians from involving themselves in India's politics. His view was supported by J. M. Sen Gupta, the mayor of Calcutta, who gave an interview to the Malaya Tribune entitled, 'Indians Overseas: How they can Help the Motherland', Malaya Tribune, 21 February 1930, p. 11.

${ }^{26}$ Malaya Tribune, 26 May 1937, p. 11. See also Ampalavanar, 'Social and Political Developments', pp. 6o-61.

${ }^{27}$ The Indian, 5 June 1937, quoted in Ampalavanar, 'Social and Political Developments', p. 69 .

${ }^{28}$ Stenson, Class, Race, pp. 40-46. 
explaining that this was seen as a topic best kept out of Malayan public discussion. ${ }^{29}$

A further difference between the Indians and Chinese in Malaya was that, while Chinese political problems were equally significant in both the Federated Malay States and the Straits Settlements, Indian issues were mostly confined to the Federated Malay States. This is because the main problems of the Indian community were specific to conditions in the Malay States, for example, the treatment of labourers, the bulk of whom were employed as plantation labour in the peninsular mainland, as well as the systemic political and social discrimination against Indians that existed in the Malay States where ethnic Malays had greater constitutional rights. As an urban centre, Singapore did not have significant numbers of Indian plantation labourers. Furthermore, Singapore was a full British colony rather than a Britishprotected state under a traditional Malay ruler as was the case in the Malay States. This meant that non-Europeans of all ethnicities had the same constitutional status. Consequently, organizations like the Central Indian Association of Malaya were based in the Federated Malay States. Indians in Singapore and the other Straits Settlements, while active in campaigning on these issues, were fighting on behalf of their brothers in the Malay States rather than in their own interests.

\section{Race and nation}

Another characteristic of a nation is that it can be linked to a particular race. This idea arose in Western European nationalisms during the late nineteenth century when there were significant developments in the concept of race. Darwinian evolution provided a scientific reason for racial variations and enabled the genetic classification of people into different races. New racial theories then interacted with linguistic and nationalist ideas. It was easy to inaccurately equate race with language as the two often overlapped, while the link between race and nation was encouraged by the practice of using the term 'race' synonymously with 'nation'. ${ }^{30}$ This usage was widespread in official

${ }^{29}$ The Malaya Tribune stated its policy repeatedly, for example in 6 March 1931, p. 8 and 21 April 1932, p. 11 .

${ }^{30}$ E. J. Hobsbawm, Nations and Nationalism Since I780: Programme, Myth, Reality, $2^{\text {nd }}$ edition (Cambridge: Cambridge University Press, 1990) pp. 107-09. 
colonial sources from Malaya, as well as in readers' letters in the Malaya Tribune at the beginning of the r 1930 s.

At a time of intense interest in new Asian nationalisms, the strongest influence that caused people in Malaya to equate 'race' with 'nation' was not standardized colonial usage, but the debates on the nature of nationalism in China and India. The conflation of 'race' and 'nation' worked in tandem with the idea that a person's ethnicity was determined by familial descent. This was particularly prevalent in official Chinese thought, as can be seen from the fact that Chinese nationality law was based on jus sanguinis. ${ }^{31}$ All ethnic Chinese were therefore automatically part of the Chinese nation in racial and legal terms. To Chinese nationalists, 'a Chinese is always a Chinese no matter where he goes'; in other words, biologically defined race was believed to determine one's cultural identity. This meant that all Chinese were expected to have a common Chinese culture and ability in the national language of China, Mandarin. Straits Chinese reactions to their dual nationality clearly demonstrated that the Straits Chinese did not agree with this formulation of ethnic and national identity.

The flip side of the assumption that a Chinese person had a naturally intimate relationship with all things Chinese was that a non-Chinese could not understand or be associated with something seen to be Chinese. This point was illustrated when a group of Indians set up a private school in Singapore called the Sun Yat Sen Memorial Institution in late 1929, much to the anger of Chinese readers of the Malaya Tribune. The latter were strongly proprietorial over the symbols of China's nationalism and national identity, with one reader asking what right an Indian had to make use of Dr Sun's name because 'we have every right and monopoly over things that are our own, and it is our duty to see that nothing is taken from us without our consent' ${ }^{32}$ At the heart of objections to the school was the belief that a person's identity was entirely related to his ethnicity. Readers suggested that for an Indian not to choose a figure from his own race, such as Tagore or Gandhi, indicated that they had 'lost his love for his motherland' and was therefore not to be trusted.

${ }^{31} \mathrm{CO} 273 / 5^{8} 5 / 13008 / 4, M R C A 37$ (September 1933), p. 15 .

${ }^{32}$ Letters on this issue appeared in Malaya Tribune, 15 October 1929 , p. $5 ; 16$ October 1929, p. 11; 25 October 1929, p. 11; 4 November 1929, p. 4; 6 November 1929, p. 12; 13 November 1929, p. 2; 16 November 1929, p. 3; 19 November 1929, p. 7; 21 November 1929, p. 11; 22 November 1929, p. 11 ; 23 November 1929, p. 5; 26 November 1929, p. 3; 27 November 1929, p. 2; and 28 November 1929, p. 2. 
The view that 'a great man transcends all creeds, colour and caste' and 'becomes an international figure' such that 'the hero of the Chinese is thus a hero of the Indians as well' ${ }^{33}$ did not gain much support from Malaya Tribune readers. Despite the fact that not many shared this viewpoint, here was an indication that reductionist notions of the immutable ties between nation, race, and identity were being challenged. A few readers wrote in to the Malaya Tribune to condemn 'that narrow nationalism which is the bane of all progress and the blight of all unity'34 as was displayed in the furore over the Sun Yat Sen Memorial Institution and opined that racial amity on an international scale was the direction in which the world was heading. ${ }^{35}$ 'Internationalism' was taken to be the opposite of 'nationalism', and its most thorough expression was considered to be miscegenation, which was derogatorily termed 'blood amalgamation' or 'heterogeneous coupling' by Yao Enguan, an outspoken promoter of the China nationalist cause. ${ }^{36}$ One letter-writer to the Malaya Tribune expressed the view that 'an Indian marrying a Chinese or vice versa is a step to be desired in this country... It is time that in this country we relegated our different nationalities to the limbo of things forgotten and joined hands to make a Malayan nation. ${ }^{37}$ The coexistence of different races in Malaya made it a natural place for internationalism to be promoted and there were suggestions that the best way of developing a 'Malayan spirit' was by interracial marriage. This idea was supported by various other parties such as a reader of the Malaya Tribune, participants in an inter-club debate between the Chinese Christian Association and the Chinese Students' Literary Association on the topic, as well as the Straits Echo newspaper. ${ }^{38}$ However, they were very much a minority. In general, there were more people in favour of international racial amity who were not prepared to go as far as to suggest intermarriage. ${ }^{39}$

${ }^{33}$ Malaya Tribune, 26 November 1929, p. 3 .

${ }^{34}$ Malaya Tribune, 16 November 1929, p. 3 .

${ }_{35}$ Malaya Tribune, 16 November 1929, p. 3; see also 28 September 1929, p. 11 ; and 26 November 1929, p. 3 .

${ }_{36}$ Malaya Tribune, 19 November 1929, p. 7.

${ }^{37}$ Malaya Tribune, 29 September 1929, p. 11.

${ }_{38}$ Malaya Tribune, 10 October 1929, p. 11; 7 December 1929, p. 3; 25 April 1930, p. 13 .

${ }^{39}$ See, for example, Malaya Tribune, 25 October 1929, p. 11; 26 November 1929, p. 3; 16 November 1929, p. 3; 27 November 1929, p. 2; and 17 December 1929, p. 4 . 


\section{Language and nation}

Besides equating 'race' and 'nation', many nationalist movements made the assumption that each race was identified with a particular language and that this language would be one of the primary characteristics of the racially defined nation. This idea was particularly true of the developing Chinese and Indian nationalisms. Each of these countries was at different stages in the development of linguistic nationalism. While Mandarin had already been established as the new national language of China, ${ }^{40}$ in India, there was still dispute as to whether Hindi should play a similar role in India. Indian and Chinese readers of the Malaya Tribune argued over which country had achieved greater linguistic unity in its nation-building efforts. Some Indians conceded that Hindi was not yet spoken widely enough to be considered India's lingua franca and that English 'occupies that place that is legitimately Hindi's', but went on to express the belief that Hindi was 'fast advancing and in time to come the whole of India will have one common language just as Mandarin will be in China'. ${ }^{41}$

The problem that most concerned the readers of the Malaya Tribune was the learning of Mandarin by the Chinese in Malaya. ${ }^{42}$ The function of a nationalist language is illustrated by the way in which some people saw Mandarin as a means by which to enforce a cultural unity to

${ }^{40}$ In 1913, the Conference on Unification of Pronunciation held in Peking adopted Mandarin as a standard language, calling it Guoyu (national language), with the intention that it would be used not just in official communication, but also as a replacement for regional dialects in daily life. The Kuomintang-dominated government, which was established in Nanking in 1927, extended the nationalistic significance of Guoyu when it became the standard language (Biaozhunyu) of the Chinese minzu (translated variously as 'nation', 'nationality' or 'ethnic group') envisaged as a single people inhabiting a unitary state which had as its ideal a single language spoken by all. See John DeFrancis, The Chinese Language: Fact and Fantasy (Honolulu: University of Hawaii Press, 1984), pp. 224-25; for fuller discussion, see John DeFrancis, Nationalism and Language Reform in China (New York: Octagon Books, 1972).

${ }^{41}$ For example, see letters in Malaya Tribune, 27 September 1929, p. 11; Malaya Tribune, 4 October 1929, p. 11; Malaya Tribune, 10 October 1929, p. 11 ; and 9 October 1929, p. 10.

${ }_{42}$ Letters on the debate were published in Malaya Tribune, 17 May 1929, p. 11; 27 May 1929, p. 4; 28 May 1929, p. 12; 29 May 1929, p. 11; 31 May 1929, p. 4; 1 June 1929, p. 12; 3 June 1929, p. 12; 4 June 1929, p. 12; 5 June 1929, p. 11 ; 26 August 1929 , p. 11; 11 September 1929, p. 11; 12 September 1929, p. 11; 16 September 1929, p. 11 ; 19 September 1929, p. 11 ; 20 September 1929, p. 5; 21 September 1929, p. 10; 25 September 1929, p. 11; 26 September 1929, p. 11; 28 September 1929, p. 11; 1 October 1929, p. 11; 2 October 1929, p. 11; and 3 October 1929, p. 11. 
accompany the unity imposed by the genetic racial characteristics of the Chinese nation. One Malaya Tribune reader opined that it was necessary for the Straits Chinese to learn Mandarin so that the 'significant difference in manners, customs, speech between the local Chinese and those at home' might be checked and the Straits Chinese could be prevented from becoming 'a band of wayward wanderers quite independent of the Chinese race'. The overlapping of racial, linguistic, cultural, and political identities was emphasized when the same writer declared that all Chinese should be proud of the fact that they were 'sons of a rising republic' ${ }^{43}$ Some went as far as to link language with national survival. At a debate organized by the Straits Chinese Literary Association on whether 'the study of Chinese should be made compulsory for Overseas Chinese', the main speaker for the proposition, Yao Enguan, expanded on this line of argument by explaining that 'a nation that did not preserve its own literature was liable to extirpation' as exemplified by 'the Red Indians and the negroes'. When the motion was put to a vote, the proposition won by an overwhelming majority. ${ }^{44}$ In choosing the language of nationalist movements, the prescribed political significance of the language was a more important consideration than ethnic heritage. Although many Straits Chinese could converse in a Chinese dialect, this was not sufficient to avoid them being looked down on by those who considered it a necessary characteristic of being a Chinese to have a spoken and written knowledge of Mandarin. By consistently referring to the Mandarin language as 'Chinese' or the 'mother tongue', Chinese nationalists reinforced the idea that Mandarin was synonymous with Chinese ethnicity, thereby ignoring the reality that other dialects were the true 'mother tongue' of most Chinese.

The relationship between Mandarin and Chinese dialects was replicated in the way in which Hindi took preference over Tamil in the Indian nationalist movement. In contrast to the low status ascribed to Chinese dialects, Tamil was able to present a more formidable challenge to the spread of Hindi. By 1930, a bourgeoning Tamil subnationalism had spread from India to Malaya. ${ }^{45}$ There were readers' letters to the Malaya Tribune encouraging the use of Tamil, ${ }^{46}$ a Tamils

${ }^{43}$ Malaya Tribune, 16 September 1929, p. 11.

${ }^{44}$ Malaya Tribune, 15 June 1929 , p. 9.

${ }^{45}$ For an account of the Hindi language movement in Kuala Lumpur, see Ampalavanar, 'Social and Political Developments', pp. 66-67.

${ }_{46}$ Readers' letters on the Tamil language were published in Malaya Tribune, 17 February 1930, p. 11; 20 February 1930, p. 11; 26 February 1930, p. 3; 28 February 
Reform Association was formed in Singapore in 1931, and the Tamil Murasu daily newspaper was established in 1932 as the Association's organ. ${ }^{47}$ As the majority of South Asians in Malaya were Tamils, the promotion of Tamil rather than Hindi had a greater resonance with them.

In the acrimonious debate on learning Mandarin, there was one thing both sides agreed upon: that a person should ideally be bilingual in both English and Mandarin. The real dispute lay in deciding which of these two languages should be the primary language and which the second language. The fact that the English-literate Chinese readers of the Malaya Tribune were divided between the two opposing viewpoints illustrates that the English-speaking Chinese community varied greatly in their interpretation of Chinese identity. Those who believed that a child should be educated first in Chinese founded their arguments on the principle that all ethnic Chinese had a duty to learn their 'national language'. It was an integral part of their 'nationality' and identity, and to not know their own language was a disgrace. Even if a Chinese education did not bring the same economic and employment benefits as schooling in English, it was imperative and natural that Chinese children should receive their early education in Mandarin. Some also thought that there was a good chance that overseas Chinese would go back to China to work, so learning the national language was important in order for them to participate in the 'reconstruction of China, which... involves the whole of the Chinese race'. ${ }^{48}$ Others, such as the Chinese correspondent of the Malaya Tribune, felt that although it was worthwhile to learn Chinese as a second language, English should take precedence as it was the most useful language in a British colony, as well as in an international context. ${ }^{49}$

In India and China too, there were supporters of the English language among the nationalists. Those who argued for English

1930, p. 3; 3 March 1930, p. 2; 4 March 1930, p. 11; 8 March 1930, p. 4; and 11 March 1930, p. 11.

47 Rajeswary Ampalavanar, 'Tamil Journalism and the Indian Community in Malaya, 1920-1941', Journal of Tamil Studies, 2 (2), 1970, pp. 51-53; Vasandakumari Nair, 'Tamils Reform Association, Singapore (1932-61)', Academic Exercise, University of Singapore, 1972, pp. $15^{-18}$; S. Arasaratnam, 'Social Reform and Reformist Pressure Groups Among the Indians of Malaya and Singapore 1930-1955', Journal of the Malaysian Branch of the Royal Asiatic Society, 4o (2), December 1967, p. 59; Stenson, Class, Race, p. 40.

${ }^{48}$ Malaya Tribune, 27 May 1929, p. 4 .

${ }^{49}$ Malaya Tribune, 20 September 1929, p. 5 . 
as the lingua franca of India felt that the 'democratic spirit' and reforming ideas which accompanied the spread of English education outweighed the practical difficulties of educating the masses in a foreign tongue. ${ }^{50}$ Commentators on China echoed this belief in the modernizing influence of English. Qian Xuantong, a well-known Chinese radical intellectual, believed that replacing the Chinese language with Esperanto or English was the only way to effect true reform in China. ${ }^{51}$ Similarly, in an article on Westernizing and modernizing China that was published in the Malaya Tribune in 1932, Goldstein Chen, a Hong Kong University graduate, recommended that English be made the national language of China. ${ }^{52}$

The English language movement received strong support in Malaya. When the issue of Malaya's lingua franca was discussed in 1934, in the context of whether the medium of free government primary education across British Malaya should be in English or Malay, advocates of the English language were in the overwhelming majority in the Straits Settlements. Many used the same arguments about the modernizing influence of the English language as the pro-English reformers in China and India. In both the Chinese and Indian communities, there was a recognition that under British rule, ethnic languages could at most be given equal emphasis with English and not supersede it. Early Straits Chinese settlers in Malaya had quickly realized that an English education opened the doors to commercial and professional opportunity under British rule.

While this remained fundamentally true, the economic value of bilingualism was gradually becoming more evident. By the mid1920 , it was common knowledge that English-educated boys were having difficulty finding clerical employment, particularly in Penang and Malacca. ${ }^{53}$ The Great Depression of the early 1930 aggravated the problem and gave rise to high rates of clerical unemployment. In a competitive labour market, someone who was literate in both

${ }^{50}$ Malaya Tribune, 10 April 1930, p. 11; 26 April 1930, p. 4; and 30 April 1930, p. 11.

${ }^{51}$ Qian Xuantong was among the most extreme of the central leaders of the New Culture Movement during the May Fourth Movement period in China. His ideas on Chinese language reform were expounded in his essay 'Zhongguo jinhou de wenzi wenti' (中國今後的文字問題, 'The Problem of Present-Day China's Writing System'), in Xin qingnian (新青年) 4 (4), 15 April 1918, pp. 350-55.

52 Malaya Tribune, 25 October 1932, p. 4 .

53 Straits Echo, 22 March 1926, p. 8; Jasbir Kaur Dhaliwal, 'English Education in the Straits Settlements and Federated Malay States, 1896-1941', Academic Exercise, University of Malaya, Singapore, $19^{61}$, pp. $14^{-1} 5^{\text {. }}$ 
English and Chinese would have had an advantage in finding clerical employment or expanding commercial contacts with Chinese firms than someone who was monolingual. ${ }^{54}$ While at one time an English education had been justified as being undertaken purely for materialistic reasons, now learning Mandarin was also economically desirable and not merely for cultural interest.

The language debate among Tamils used much the same argument. Several correspondents advocated the learning of Tamil alongside English for Tamils in Malaya, with some recommending that Hindi be taken as a third language as well. Supporters of Tamil pointed out that Tamil had cultural value and transmitted moral values as well as being functional for business purposes, as was evidenced by the fact that Chettiars conducted their business and kept their record-books in Tamil. Just as the Straits Chinese were criticized for educating their children in English for pragmatic reasons, English-educated Tamils were accused of being overly materialistic in learning English at the expense of their own language. Ultimately, in the discussions about both Hindi and Tamil, bilingualism was accepted as the ideal solution. English would continue to be a worthwhile language to learn, both for the potential leadership elite of India and for the wider population of Indians in Malaya for whom it would bring economic opportunities.

Bilingualism, however, was a privilege not all could afford. As studies of other nationalisms have noted, linguistic revivals have tended to be led by the educated middle class, rather than the working class. ${ }^{55}$ In the Malayan context, local-born Chinese whose families were not well off chose to have their children educated in English because those who were literate only in English had better employment opportunities than their counterparts who were literate only in Chinese. Although language schools and Mandarin classes mushroomed at the beginning of $1930,{ }^{56}$ many people found it difficult to afford the class fees. The Malaya Tribune published numerous pleas for the Singapore Chinese Mandarin School to reduce its fees from

${ }^{54}$ Malaya Tribune, 14 February 1931, p. 13; and 24 April 1931, p. 11.

${ }^{55}$ Hobsbawm, Nations and Nationalism, pp. $112-18$.

56 The formal inauguration of the Singapore Chinese Mandarin School took place on 4 January 1930 and classes began two days later; see Malaya Tribune, 6 January 1930, p. 8. Classes for the Chinese National Language School began on 15 February 1930; see Malaya Tribune, 9 January 1930, p. 11; and 25 January 1930, p.11. Other organizations such as the Nanyang Chinese Students' Society also offered language classes; see Malaya Tribune, 27 March 1930, p. 2. 
$\$ 5$ per month to $\$ 2$ or $\$ 3$ per month. ${ }^{57}$ Consequently the school lowered the fees to $\$ 3$, but only for schoolchildren. ${ }^{58}$ The ideal solution would have been to have Mandarin taught as a second language in the Christian mission and government English-medium schools in Malaya. However, the only other languages taught in these schools were French and Latin. The consensus in favour of bilingual English and Mandarin education was an important criticism of the existing education system. Educational policy reforms proposed by Governor Clementi in 1933 did nothing to cater to the interests of the large Chinese population in the Straits Settlements as the proposed free government primary education for all races was to be taught only in the Malay language.

Ironically, the impassioned views of ardent Chinese nationalists in Malaya worked against the very cause they were trying to promote. Vicious letters were published in the Malaya Tribune, lambasting the Straits Chinese for having no knowledge of written Chinese and speaking English and Malay instead. ${ }^{59}$ The result was that many Straits Chinese who had been interested in learning Mandarin for some time were 'sickened' by the verbal attacks from 'zealous crusaders' whose actions only 'weaken[ed] the cause they claim[ed] they [were] endeavouring to further' ${ }^{60}$ The general consensus was that the Straits Chinese were trying their best to redress their lack of fluency in Mandarin and resented attacks on their ancestors who had only done was what necessary to adapt and make a living for their families in Malaya. ${ }^{61}$

\section{Conclusion}

Domiciled Chinese and Indians actively questioned the factors contributing to nationhood by using their own situation as Chinese or Indians in a foreign land to examine the assumptions of nationalisms from China and India. By comparing the respective situations in each of these countries, people in Malaya added a new depth to

${ }^{57}$ Malaya Tribune, 20 November 1929, p. 1 1; 29 November 1929, p. 2; 9 December 1929, p. 11; 13 December 1929, p. 11 ; 11 January 1930, p. 11; 24January 1930, p. 2; and 24 February 1930, p. 11.

${ }_{58}$ Malaya Tribune, 11 March 1930, p. 11; and 25 March 1930, p. 11.

${ }_{59}$ Malaya Tribune, 17 May 1929, p. 11; 27 May 1929, p. 4; 29 May 1929, p. 11; 11 September 1929, p. 11; 16 September 1929, p. 11 ; and 26 September 1929, p. 11.

${ }_{60}$ Malaya Tribune, 21 September 1929, p. 10.

${ }^{61}$ Malaya Tribune, 21 September 1929, p. 10; and 1 October 1929, p. 11. 
their discussions on nationalism and national identity. Their own circumstances proved that being 'Chinese' or 'Indian' could encompass a range of political, cultural, and linguistic characteristics, rather than a homogenous identity as promoted by the bourgeoning nationalisms. Chinese and Indians in Malaya found ways to combine the realities of life in British Malaya with a revival of interest in their ethnic homelands. While they found no reason to adopt the anti-imperialist or specifically anti-British politics of China and India, they were inspired enough by the political progress and consequent rise in prestige of China and India to reacquire the linguistic and cultural knowledge that had been diluted by generations of settlement in Malaya. Yet new ethnic awareness did not come at the expense of identifying with British Malaya and bilingualism, rather than vernacular monolingual ability, was universally approved of by domiciled Chinese and Indians. The greatest impact of ethnic revivals on the Chinese and Indians in Malaya was in the sense of pride these communities felt in being able to associate, at least racially, with the rising international status of China or India. Miscegenation was not widely accepted and this placed limits on the direction a uniquely 'Malayan' identity could take in the future.

As the discourse matured, it soon became obvious that Chinese and Indians were not only speaking to their own ethnic communities, and to the parallel transnational communities of Chinese or Indians, but that their opinions were being heard by the indigenous Malays who feared the threat of immigrant groups, and by the British authorities who were always mindful of anti-colonial influences from China and India. By the mid-1930s, Anglophone Asians had refocused their debates from the transnational identities of Chinese and Indians to their status in British Malaya itself. Once again, the Anglophone transnational communities overturned existing assumptions of nation and identity by creating the new category of 'Malayans' as a non-ethnic descriptor for people of Malaya to function alongside the existing term 'Malay', which referred specifically to the ethnic group that located its roots in Malaya. 